\title{
MOTIVATION AS AN IMPORTANT FACTOR IN STUDYING FOREIGN LANGUAGES IN A NON-LINGUISTIC HIGHER EDUCATION INSTITUTION
}

The author of the article aims to join the problem of students' motivation to learn foreign languages in a nonlinguistic higher education institution (HEI). As the students of this type of HEI demonstrate low interest in mastering foreign languages, the author considers it quite urgent. Moreover, employers require the knowledge of at least one or, even better, several foreign languages from their employees.

The successful study of a foreign language in a non-linguistic HEl is impossible without motivation for it. Therefore, the components of motivation to learn a foreign language, as well as ways to create them are considered in the article.

The results of researches of foreign and domestic scientists who have studied this problem are analysed in the article. Most authors share the view that motivation is the desire of the language learner to master it in order to achieve his or her goal: to pass the exam successfully, find a highly paid job, etc. A number of authors believe that pedagogical skill of the teacher is necessary to create proper motivation.

The definition of motivation in pedagogy and psychology is considered and analysed by the author. The author pays special attention to the process of conducting lessons, because it depends on the skill of the teacher whether the motivation that the student had at the beginning of learning a foreign language will increase or conversely, decrease.

The author shares the opinion of other researchers that the very form of educational activity and the opportunity to achieve high practical results create a prerequisite for student's motivation.

The intensification of learning activities heavily depends on the teacher who creates the atmosphere of collaboration in the classroom. As the communicative method is urgent at the present stage of foreign language learning, it is important to organize group and pair communication of students. At the same time, it is necessary to choose the right partners to have different levels of awareness.

The author emphasizes that the teacher should encourage, praise and infuse faith into students to increase their motivation. The right choice of teaching methods encourages students not only to work creatively in the classroom, but also to continue to learn the language outside the classroom through watching movies, reading magazines and books, communicating with native speakers, etc.

The article presents the results of the author's research, namely: what components form the motivation, as well as the ways of its creation. Research findings can be used by foreign language teachers in their practical work.

Key words: motivation problem, components of motivation, ways to create motivation, foreign languages, non-linguistic, higher education institution, teacher's skill.

Problem statement. The problem of students' motivation to learn foreign languages in a nonlinguistic higher education institution $(\mathrm{HEI})$ is one of the most important problems at the current stage of foreign language teaching, as motivation determines the productivity of learning activities and is its organic component. The urgency of the problem of motivation is due to the fact that it is closely related to the issues of activation, individualization, intensification of the activity of a particular person in certain circumstances and situations.

It has been observed that the students of a nonlinguistic $\mathrm{HEI}$ have a rather low interest in mastering foreign languages. Recognizing that the knowledge of a foreign language (primarily English) is one of the conditions for a successful career today, however, students do not pay due attention to this subject, which is reflected in results that do not satisfy neither students nor their teachers.

According to V. Znanetsky, among the integrated requirements for a specialist of the XXI century, formulated under the auspices of UNESCO, there is a high communicative readiness, which implies the knowledge of one of the most widely spoken languages in the business world. According to many leading employers in Ukraine, foreign language proficiency now takes the second place among the requirements that they lay down to graduates of $\mathrm{HEl}$, and is inferior only to professional competence and leaves behind computer literacy [1, p. 39].

Analysis of actual researches. In foreign theory and practice of teaching the problem of motivation was investigated by R. Gardner, W. Lambert, Z. Dornay, G. Crooks, R. Schmidt, J. Keller and others. 
They focused on research into the motivation of young students in educational institutions.

Particularly popular is R. Gardner's theory of 'purposeful motivation', which defines two orientations for language learning: 1) instrumental which is related to the learner's desire to learn a language in order to achieve his or her goal, for example, passing an exam, career development, etc. 2) integrative, which is connected with the desire of the learner to learn a language through a high positive personal attitude to that language, the people who speak it, culture, etc. [2, p. 266].

Describing the socio-educational model of foreign language learning, R. Gardner emphasizes that motivation is a primary factor. He defines motivation as a set of efforts, a desire to achieve a goal, and a positive attitude to the language being learned. Other factors, such as the attitude to the learning situation and integration, in his opinion, can influence the above mentioned components of motivation [2, p. 268].

I. Zymnyaya assumes that motivation is one of the main components of the structural organization of educational activity and relates to main characteristics of the process of this activity, and is also the first obligatory component of the structure of educational activity [3, p. 35].

B. Spolsky identified four major factors that influence the successful mastering a foreign language - knowledge, skills that are in the first stage (including general knowledge of a mother tongue and otherlanguages); learning, including psychological, biological, intellectual and cognitive abilities (skills); motivation; language learning opportunities (the presence of time and other conditions, the presence of formal and informal situations in which the student can apply the acquired knowledge). Any of the above factors has a significant impact on the result: if one of them is absent, then mastering the language does not occur, the greater the influence of one of the factors, the better the result [4, p. 45].

To create a positive motivation for students to learn a foreign language, T. Wright proposes to maintain a reasonable discipline sufficient to create a work atmosphere, to show positive attitude towards students, to encourage, to cheer them up in a class, to offer students interesting tasks based on interaction with each other and joint efforts for solving an educational task. In his opinion, the teacher should show his or her own interest, organize self-assessment and self-praise by discussing work results and reports, encourage the students' opportunity to be proud of their work by presenting it in the form of posters, stands, using written feedback [5, p. 37].

The objective of the article is to identify the components of the motivation required for students to learn a foreign language in a non-linguistic $\mathrm{HEl}$ and the ways to create it.
The presentation of the main material. The motivation in psychology and pedagogy is considered differently: as a set of factors that support and direct human behavior, as a set of motives, as a certain intention that causes personality activity and determines its orientation, and as a process of mental regulation of certain activities, etc. [6, p. 20]. The researches of the motivational aspects of learning a foreign language describe the diversity of a person's motivational sphere and its complex structure. First, it can be influenced by social factors caused by the needs of society: together they form external motivation, which exists in two varieties: as broad social motivation and as narrowly personal one. Second, the motivational and stimulating sphere of a person can be influenced by the nature and course of the educational process. This is the so-called intrinsic motivation, its subspecies is the motivation for success. Both external and internal motivations can be positive and negative; in these cases it is customary to speak of positive and negative motivation. There are also types of motivation as remote (delayed) and close (relevant).

External motivation is usually remote and designed to achieve the end result of learning. It aims at the realization of a kind of super-task. External motivation defines attitudes toward mastering a foreign language as a way of asserting oneself, and sometimes as a path to personal well-being. A wide range of stimulating motives are possible here.

L. Shtokhman believes that the very form of educational activity and the possibility of achieving high practical results create a prerequisite forstimulating students. But decisive in ensuring the effectiveness of learning is a conscious consideration of the motivational factor and its management at all levels and all components of the educational process, the impact on it through the special organization of educational material, methods and techniques of its introduction and consolidation, as well as the organization of forms of group interaction [7, p. 513].

Practical classes in a foreign language, where typical consideration of problem situations and their possible solutions exists, become more effective if we use different methods of working with students such as combination of individual, group and teamwork. The variation between these methods of work within a single practical class allows to avoid the monotony and, as a consequence, the loss of students' interest in the tasks being performed.

The intensification of learning activities depends heavily on the teacher, who creates an atmosphere of collaboration. It is important that all learning activities should be motivated. When organizing group and pair communication, it is important to choose the right partners so that on the one hand they have different levels of awareness and on the other hand, that one does not oppress the activity of the other. 
In most cases, the wrong choice of pedagogical techniques can depress, and even destroy the original motivation instead of increasing it. Proper use of interest-enhancing strategies enables to turn a student who does the exercises automatically into an autonomous unit that not only works creatively in the classroom but also continues to learn the language outside the classroom through watching movies, reading magazines and books, communicating with native speakers, etc.

Due to the current state of teaching methodology, teachers who are aware of the importance of this factor often face the problem of lack of motivation. First of all, this is the case if the student does not believe in the end result or does not fully realize the purpose of the study. At the same time, motivation can be oppressed by the suggested learning tools, which may seem to students to be senseless (too old / incomprehensible/difficult, etc.). Moreover, sometimes this can be attributed to the student's reduced ability to concentrate and sloth. Undoubtedly, it is impossible to interest the listener by force, but there are ways to increase motivation.

We used the following tools:

- the principle 'do not tell but show' should be guided, that is, to give students examples of specific life situations in which the need to use certain language skills is revealed;

- it is important to know the level of audience capacity and adapt each activity depending on that level;

- to form the sense of self-efficiency of the student. A person's faith in the effectiveness of his or her own actions, a sense of self-confidence greatly increases the success of the end result. Such feelings should be formulated through verbal encouragement; diligence and effort should be encouraged first but not the student's mental capacity. Such behavior inspires students to take further actions, the fear of difficult tasks disappears and they realize the results and effectiveness of their work, which gives them the desire to constantly learn something new;

- it is necessary for the student to be aware of the usefulness of the offered knowledge. This understanding can be favoured through practice that would allow the use of theoretical knowledge to solve student's real-world problems and tasks. When they find themselves in a real situation of a similar nature among the native speakers, they will already be able to act, because they have partly overcome the fear of the new in safe conditions;

- one should not forget the advantages of innovative types of modern teaching methods: play activities, theatricals, role-playing games, etc. They help the student move beyond the traditional understanding of the learning process as hard and serious work and overcome the fear of error;
- it is necessary to remember the importance of the role of the teacher's own interest. One need to be patient and remember that students' progress is a long-term process that needs to be promoted and the results of which are not immediately apparent.

In order to motivate students to learn a foreign language, it is necessary to skillfully select materials for study. It is not necessary to focus only on the students' acquisition of formal factual knowledge, but it is necessary to teach students to analyse information about the possibility of its application to explaining new phenomena, to establish links with the previously acquired knowledge and experience, to transfer knowledge and skills from information and communication technologies and educational subjects to solving communicative tasks [8, p. 58].

Exploring the problem of motivation, we conducted a survey among the students. A total of 100 the first and second year students were interviewed. The questionnaire included three groups of questions:

- factors that students consider important to succeed in learning;

- the qualities of the teacher that are essential for successful mastery of the subject;

- foreign language aspects that students would like to study in a higher school.

The results show that motivation $(65 \%)$ is the most important factor in learning success. The second place - self-confidence $(20 \%)$, the third - ability to concentrate, be organized and disciplined (15\%).

The students' evaluation of the teacher's basic qualities was quite unexpected. In the first place students put knowledge of the subject $(25 \%)$. The ability to stimulate students confidently took the second place, gaining $22 \%$. Equally important was the sense of justice (18\%). Further students put patience (15\%), kindness (14\%), sense of humor $(5 \%)$. Teacher authoritarianism was unacceptable - $(1 \%)$.

In general, students believe that the teacher should show kindness, attention and care, approve and praise them, express confidence that the student will change for the better.

The results of the research we received are similar to those obtained by L. Ruban, namely: the low level of teacher's pedagogical skills does not contribute to students' motivation to learn foreign languages. If the teacher focuses on the right answer and not on the process of thinking and solving the problem, does not observe the activities of students during the class, constantly conducts testing, evaluation, conducts psychological wars with students - it does not contribute to the desire of students to study with such a teacher and accordingly to study the subject, which he or she teaches [9, p. 189].

As for the aspects of a foreign language that students would like to study in a non-linguistic $\mathrm{HEI}$, $80 \%$ of them would like to learn a foreign language 
in a professional direction, another $20 \%$ expressed the desire to learn everyday English (spoken) in parallel.

Conclusions and proposals. As a result of our research, we have identified the following components of motivation for students to learn a foreign language in a non-linguistic HEI:

- awareness of the need to master a foreign language for a future professional activity;

- desire to communicate with native speakers on everyday topics;

- desire to broaden a mental outlook, watch movies in a foreign language, use the Internet as many sites are in English.

The students' surveys and our own practical experience have shown us how to create the necessary motivation:

- to give examples of specific life situations;

- to consider problematic situations;

- to select training materials skillfully;

- to offer interesting tasks aimed at pair or group communication;

- to apply innovative types of tasks;

- to be positive about students;

- to infuse faith into students in the end result of study.

These ways of creating motivation will be able to help foreign language teachers bring to their students the full breadth of possible use of foreign language knowledge in the professional activities of future specialists.

\section{References:}

1. Знанецький В.Ю. Щодо розвитку мотивації студентів до вивчення іноземної мови у процесі професійної підготовки. Стратегічні прі- оритети в науці: збірник наук. матеріалів $X L$ Міжнародної наук.-практ. конф., Вінниця, 10 лютого 2020 р. С. 38-40.

2. Gardner R., Lambert W. Motivational variables in second language acquisition. Canadian Journal of Psychology. 1959. N 4, pp. 266-272.

3. Зимняя И.А. Ключевые компетенции - новая парадигма результата современного образования. Высшее образование сегодня. 2003. № 5. C. 34-42.

4. Spolsky B. Conditions for Second Language Learning. Oxford University Press, 1992. 386 p.

5. Wright T. Roles of Teachers \& Learners. Oxford University Press, 1991. 164 p.

6. Бей І. Формування позитивної мотивації студентів до використання проектних технологій у майбутній професійній діяльності вчителя іноземної мови. Збірник наукових праць Прикарпатського нац. ун-туім. В. Стесраника. 2018. Випуск 2. С. 17-25.

7. Штохман Л.М. Комунікативна складова у навчанні іноземної мови у ВНЗ. Молодий вчений. 2017. № 3(43). C. 512-515.

8. Скакун М., Матіюк Д. Підвищення мотивації студентів до вивчення німецької мови та формування готовності до непереривної освіти за допомогою сучасних інформаційно-комунікаційних технологій та мультимедійних засобів. Актуальні питання вивчення германських, романських і слов'янських мов і літератур та методики викладання іноземних мов. ДНУ ім. В. Стуса. 2018. С. 56-59.

9. Рубан Л.М. Мотивація студентів до вивчення іноземної мови на немовних фракультетах. Вісник Харківського нац. ун-ту ім. В.Н. Каразіна. 2014. № 78(1103). С. 187-190.

\section{Орищин І. С. Мотивація як важливий фактор у вивченні іноземних мов у немовному закладі} вищої освіти

Автор статті ставить за мету долучитися до проблеми мотивації студентів до вивчення іноземних мов у немовному закладі вищої освіти (ЗВО). Оскільки студенти такого типу зВО демонструють низьку зацікавленість в оволодінні іноземними мовами, автор вважає їі досить актуальною. Тим більще, що роботодавці вимагають від своїх працівників знань хоча б однієї, а ще краще декількох іноземних мов.

Успішне вивчення іноземної мови в умовах немовного ЗВО неможливе без мотивації до нього. Тому в статті розелядаються складові частини мотивації до вивчення іноземної мови, а також способи їх створення.

У статті проаналізовано результати досліджень зарубіжних і вітчизняних науковців, що вивчали цю проблему. Більшість авторів поділяють думку, що основа мотивації - бажання того, хто вивчає мову, оволодіти нею задля досягнення своєї мети: успішно скласти іспит, знайти високооплачувану роботу тощо. Ряд авторів для створення належної мотивації вважають необхідною педагогічну майстерність викладача.

У статті розглянуто визначення мотивації у педагогіці та психології і проаналізовано автором. Особливу увагу автор приділяє процесу проведення занять, оскільки саме від майстерності викладача залежить, чи збільшиться мотивація, яка була у студента на початку вивчення іноземної мови, чи, навпаки, зменшиться.

Автор поділяє думку інших дослідників, що сама фоорма навчальної діяльності і можливість досягнення високих практичних результатів створюють передумову для мотивації студентів.

Активізація навчальної діяльності значним чином залежить від викладача, який створює атмосфреру співробітниитва на занятті. Оскільки на сучасному етапі вивчення іноземних мов 
актуальним є комунікативний метод, важливо організувати групове і парне спілкування студентів. При цьому необхідно правильно підбирати партнерів, щоб у них був різний рівень інформованості.

Автор наголошує на тому, що викладачу необхідно заохочувати, хвалити, вселяти віру в студентів, щоб збільшити їхню мотивацію. Адже правильний вибір педагогічних прийомів заохочує студентів не тільки творчо працювати на занятті, а й продовжувати пізнавати мову за межами занять через перегляд фільмів, читання журналів та книг, спілкування з носіями мови тощо.

У статті викладено результати досліджень автора, а саме: які складові частини фрормують мотивацію, а також способи їі створення. Висновки з досліджень можуть використовувати викладачі іноземних мов у своїй практичній діяльності.

Ключові слова: проблема мотивації, складові частини мотивації, способи створення мотивації, іноземні мови, немовний заклад вищої освіти, майстерність викладача. 